\title{
Candida mucilagina, a New Species of Yeast Found in Decaying Cladodes of Opuntia inermis and in Necrotic Tissue of Cereoid Cacti
}

\author{
H. J. PHAFF, W. T. STARMER, $\dagger$ MARY MIRANDA, AND M. W. MILLER \\ Department of Food Science and Technology, University of California, Davis, California 95616
}

A new species of Candida has been recovered 40 times from necrotic cactus tissue occurring in widely separated geographic areas. The organism has been named Candida mucilagina because of the extremely slimy, almost watery appearance of its colonies on solid media. Eleven strains were isolated in Baja California Sur, Mexico, where its principal host plant was Stenocereus gummosis (agria), and 29 strains came from rotting cladodes of Opuntia inermis in New South Wales and Queensland, Australia. The base composition of the nuclear deoxyribonucleic acid of $C$. mucilagina is 43.2 to $44.0 \mathrm{~mol} \%$ (range of five strains). The type strain of $C$. mucilagina is UCD-FS\&T 76-236C (= ATCC $42174=\mathrm{CBS}$ 7071).

During a survey of yeasts associated with necroses of Mexican columnar cacti of the North American Sonoran Desert and opuntia cacti of eastern Australia, we isolated 40 strains of a slimy, asporogenous, multilaterally budding yeast that represents a new species of the genus Candida sensu Yarrow and Meyer (9). On the isolation medium, the colonies of the new species could be easily recognized by their highly mucous, nearly watery appearance, which led us to name it Candida mucilagina sp.nov. The Mexican strains were nearly all associated with agria cacti (Stenocereus gummosis (Engelm.) Gibson and Horak), and those from Australia were all isolated from rots in Opuntia inermis de Candolle.

\section{MATERIALS AND METHODS}

Samples of necrotic cactus tissue were collected from eight areas of Baja California Sur, Mexico in the North American Sonoran Desert (Table 1, Fig. 1). These collections were part of an extensive survey of this region carried out in March 1976. Additional samples were collected in Australia in 1977 and 1978 by J. S. F. Barker, University of Sydney, New South Wales, from decaying cladodes of $O$. inermis growing in New South Wales and Queensland (Table 1). The 1977 strains (strains 12 through 17) were isolated by $\mathrm{J}$. S. F. Barker and mailed to Davis for identification. The 1978 strains (strains 18 through 40) were isolated in Davis from samples of cactus rot airmailed to the University of California (Table 1).

Most of the isolations were accomplished by streaking a loopful of necrotic tissue directly on acidified yeast extract-malt extract agar (Difco YM agar + $0.7 \%$ $[\mathrm{vol} / \mathrm{vol}] 1 \mathrm{~N} \mathrm{HCl}=\mathrm{AYM}, \mathrm{pH} 3.7$ to 3.8 ) in the field

† Present address: Department of Biology, Syracuse University, Syracuse, NY 13210. or in the laboratory. In some cases, dilutions of the tissue were made in sterile water as described earlier (6). The plates were stored at ambient temperatures $\left(24\right.$ to $\left.30^{\circ} \mathrm{C}\right)$ until colonies appeared. Counts of morphologically distinct colony types were then made, and for identification, a representative of each type was brought into pure culture by two successive platings on YM agar.

Identification was done by standard methods currently used in yeast taxonomy (8). Deoxyribonucleic acid (DNA) extraction and purification were done by a combination of the procedures of Marmur (2) and Bernardi et al. (1), as described by Price et al. (3). The guanine plus cytosine $(\mathrm{G}+\mathrm{C})$ content of the DNA was calculated from buoyant density values in cesium chloride $(4,7)$ and was based on two or three separate determinations. Micrococcus luteus (syn.: "Micrococcus lysodeikticus" [not on the Approved Lists (5)]) strain 2039 (International Collection of Phytopathogenic Bacteria, Department of Bacteriology, University of California, Davis) DNA, with a buoyant density of $1.7311 \mathrm{~g} / \mathrm{ml}$, was used as a reference. The buoyant density of the " $M$. lysodeikticus" DNA was derived from comparison with plasmid-free Escherichia coli K-12 DNA, the buoyant density of which was taken to be $1.7100 \mathrm{~g} / \mathrm{ml}$.

\section{RESULTS}

Latin diagnosis of Candida mucilagina sp. nov. In extracto malti cellulae sphaericae, interdum ovoideae, (3.2-7.9) $\times(3.9-7.9) \mu \mathrm{m}$, singulae, binae, interdum ternae; post dies 6 annulus et sedimentum non formantur. Post dies 21 annulus tenuis et sedimentum formantur.

Cultura in agaro malti post dies $21\left(25^{\circ} \mathrm{C}\right)$ mucosa, glabra, nitida; cellulae capsulae.

In agaro farinae Zea maïs post dies 14 pseudomycelium vel mycelium verum nullum.

Fermentatio glucosi nullum. 
TABLE 1. Localities and sources of isolates of C. mucilagina

\begin{tabular}{|c|c|c|c|}
\hline Serial no. & $\begin{array}{l}\text { UCD-FST strain } \\
\text { no. }\end{array}$ & Locality $^{a}$ & Habitat/substrate \\
\hline$\overline{1}$ & $76-214 \mathrm{~B}$ & $\begin{array}{l}\text { Rancho Cuñaño, Baja Calif. Sur, } \\
\text { Mexico (a) }\end{array}$ & $\begin{array}{l}\text { Stenocereus thurberi (Engel- } \\
\text { mann) Buxbaum (organ } \\
\text { pipe) }\end{array}$ \\
\hline 2 & $76-266 \mathrm{~B}$ & $\begin{array}{l}\text { Punta Pescadero, Baja Calif. Sur, } \\
\text { Mexico (b) }\end{array}$ & $\begin{array}{l}\text { Stenocereus gummosis (Engel- } \\
\text { mann) Gibson and Horak } \\
\text { (agria) }^{b}\end{array}$ \\
\hline 3,4 & $76-324 \mathrm{C}, 76-236 \mathrm{C}$ & $\begin{array}{l}\text { Todos Santos, Baja Calif. Sur, } \\
\text { Mexico (c) }\end{array}$ & S. gummosis \\
\hline 5 & $76-318 \mathrm{C}$ & Loreto, Baja Calif. Sur, Mexico (d) & S. gummosis \\
\hline 6,7 & $76-329 \mathrm{C}, 76-380 \mathrm{C}$ & Mulegé, Baja Calif. Sur, Mexico (e) & S. gummosis \\
\hline 8 & $76-354 \mathrm{C}$ & $\begin{array}{l}12 \mathrm{~km} \text { South of Mulegé, Baja Calif. } \\
\text { Sur, Mexico }\end{array}$ & S. gummosis \\
\hline 9 & $76-365 \mathrm{~B}$ & $\begin{array}{l}\text { San Jose de Castro, Baja Calif. } \\
\text { Sur, Mexico (f) }\end{array}$ & S. gummosis \\
\hline 10 & $76-370 \mathrm{~B}$ & $\begin{array}{l}\text { San Ignacio, Baja Calif. Sur, Mex- } \\
\text { ico (g) }\end{array}$ & S. gummosis \\
\hline 11 & $76-388 \mathrm{C}$ & $\begin{array}{l}\text { Bahia San Nicolás, Baja Calif. Sur, } \\
\text { Mexico (h) }\end{array}$ & S. gummosis \\
\hline 12,13 & $77-27,77-166$ & $\begin{array}{l}\text { Yarrawonga, New South Wales, } \\
\text { Australia (170 km NNW of Syd- } \\
\text { ney) }\end{array}$ & Opuntia inermis de Candolle \\
\hline 14,15 & $77-228 B, 77-247 \mathrm{C}$ & Yarrawonga & $O$. inermis \\
\hline 16,17 & $77-248 \mathrm{~A}, 77-249 \mathrm{~B}$ & Yarrawonga & $O$. inermis \\
\hline 18,19 & $78-191,78-206 \mathrm{~B}$ & Yarrawonga & O. inermis \\
\hline 20,21 & $78-214 A, 78-218$ & Yarrawonga & $O$. inermis \\
\hline 22,23 & $78-231,78-264 \mathrm{~B}$ & Yarrawonga & O. inermis \\
\hline 24,25 & $78-265 B, 78-266 A$ & Yarrawonga & O. inermis \\
\hline 26,27 & $78-345,78-360$ & Yarrawonga & O. inermis \\
\hline 28 & $78-361 \mathrm{~A}$ & Yarrawonga & O. inermis \\
\hline 29,30 & $78-538 \mathrm{~F}, 78-539 \mathrm{E}$ & Borallon, Queensland, Australia & O. inermis \\
\hline 31,32 & $78-544 \mathrm{~A}, 78-550 \mathrm{C}$ & $\begin{array}{l}\text { Grand Chester Hill, Queensland, } \\
\text { Australia }\end{array}$ & O. inermis \\
\hline 33 & $78-552 \mathrm{C}$ & & \\
\hline 34,35 & $78-556 \mathrm{~B}, 78-557 \mathrm{D}$ & Hemment, Queensland, Australia & O. inermis \\
\hline 36,37 & $78-559 \mathrm{~B}, 78-567 \mathrm{D}$ & & \\
\hline 38,39 & $78-576 \mathrm{D}, 78-587 \mathrm{~A}$ & Hemment & O. inermis \\
\hline 40 & $78-601 \mathrm{D}$ & Hemment & O. inermis \\
\hline
\end{tabular}

${ }^{a}$ Letters in parentheses indicate the map localities depicted in Fig. 1.

${ }^{b}$ Common names of cacti are given in parentheses.

Glucosum, galactosum, L-sorbosum (interdum lente), maltosum (raro nullum), saccharum (raro nullum), cellobiosum, trehalosum (valde aut lente), lactosum (lente aut nullum), melezitosum (raro nullum), D-xylosum, L-arabinosum, Lrhamnosum (interdum lente), ethanolum (interdum lente), glycerolum, ribitolum (interdum lente), D-mannitolum (variabile), D-glucitolum (valde aut lente), alpha-methyl D-glucosidum, salicinum, glucono- $\delta$-lactonum (lente, exigue), acidum lacticum (exigue aut nullum), acidum succinicum (exigue, lente) assimilantur at non melibiosum, raffinosum, inulinum, amylum solubile, D-arabinosum, D-ribosum, erythritolum, methanolum, galactitolum, acidum citricum, inositolum nec hexadecanum.

Nitras kalii non assimilatur; ethyl aminum non assimilatur.
Ad crescentiam vitamina externi necessariae sunt.

Crescere potest in temperatura $37^{\circ} \mathrm{C}$, interdum in $39-42^{\circ} \mathrm{C}$.

$\mathrm{G}+\mathrm{C}$ acidi deoxyribonucleati $=43.2-44.0$ $\mathrm{mol} \%$ (5 stirpes, vide tabulum 2 ).

Amylum fit; gelatinum non liquescit.

Typus: Stirps UCD (FS\&T) 76-236C ex tabidosis sacculis cacti Stenocereus gummosis isolata est.

In collectione zymotica Centraalbureau voor Schimmelcultures, Delphi Batavorum sub no. 7071 deposita est.

Standard description of Candida mucilagina sp. nov. Growth in malt extract: after 6 days at $25^{\circ} \mathrm{C}$ the cells are spheroidal to globose, sometimes ovoidal, 3.2 to 7.9 by 3.9 to $7.9 \mu \mathrm{m}$, single, in pairs, and sometimes in groups of three, 
surrounded by a mucilaginous capsule (Fig. 2); a pellicle, ring, and a visible sediment are lacking. After 21 days a thin ring and a moderate amount of sediment are present.

Growth on malt agar: After 21 days at $25^{\circ} \mathrm{C}$,

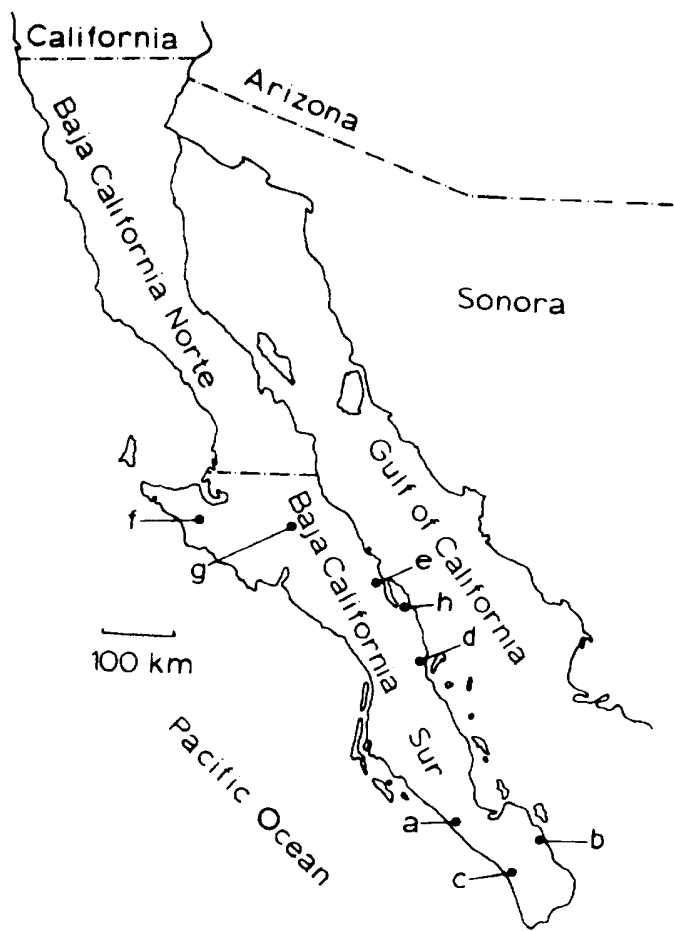

Fig. 1. Collection localities for isolates of C. mucilagina listed in Table 1.
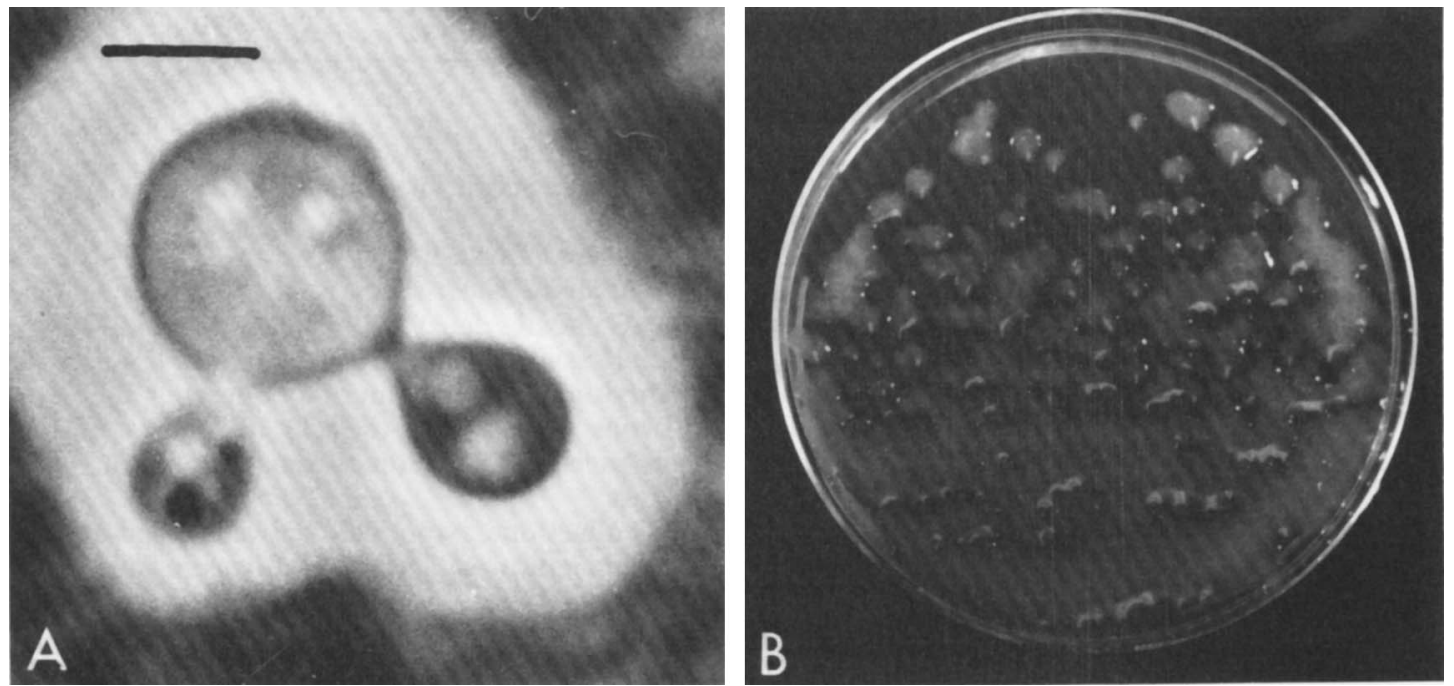

the streak culture is watery and very slimy. The growth runs to the bottom of the tube.

Dalmau plate culture on cornmeal agar: Pseudohyphae or true hyphae are lacking.

Other characteristics: Ability to ferment glupounds: D-glucose, D-galactose, L-sorbose (sometimes latent), maltose (rarely negative), sucrose (rarely negative), cellobiose, trehalose (strong or latent), lactose (latent or negative), melezitose (rarely negative), D-xylose, L-arabinose, L-rhamnose (sometimes latent), ethanol (sometimes latent), glycerol, ribitol (sometimes latent), Dmannitol (some strains negative), D-glucitol (strong or latent), $\alpha$-methyl D-glucoside, salicin, glucono- $\delta$-lactone (latent and weak), DL-lactic acid (weak or negative), and succinic acid (latent and weak) are assimilated. The following compounds are not assimilated: melibiose, raffinose, inulin, soluble starch, D-arabinose, D-ribose, erythritol, methanol, galactitol, citric acid, mesoinositol, and hexadecane.

Assimilation of nitrogen compounds: Potassium nitrate, negative; sodium nitrite, negative; ethyl amine, negative; ammonium sulfate, positive.

Growth in vitamin-free medium: Absent. Thiamine is required. Biotin is stimulatory.

Growth on $50 \%$ (wt/wt) glucose yeast extract agar: Absent.

Growth on osmotic salt agar: On 5\% $\mathrm{NaCl}$ plus $5 \%$ glucose-yeast extract agar, moderate growth; on $7.5 \% \mathrm{NaCl}$ plus $5 \%$ glucose-yeast extract agar, absent. cose is absent. Assimilation of carbon com-

Fig. 2. (A) Budding cell of C. mucilagina surrounded by a capsule; (B) slimy, watery colonies on malt agar. The bar represents $5 \mu \mathrm{m}$. 
Maximum temperature for growth: 37 to $39^{\circ} \mathrm{C}$ (a few strains from Mexico grew at $42^{\circ} \mathrm{C}$ ).

Acid formation on chalk agar: Negative.

Hydrolysis of urea: Negative.

Gelatin liquefaction: Negative.

Casein hydrolysis: Negative.

Lipolytic activity: Negative.

Formation of starch-like compounds: Positive (upon addition of Lugol's iodine, a greenish-blue color develops).

Growth in the presence of $0.1 \mathrm{mg}$ of cycloheximide per ml: Positive.

Coenzyme $\mathbf{Q}$ system: Q-8

$\mathrm{G}+\mathrm{C}$ content of the nuclear DNA: 43.2 to 44.0 mol\% (five strains, Table 2).

Habitat: Forty strains were recovered from rotting cactus tissue in the North American Sonoran Desert (principal host plant: Stenocereus gummosis) and in Eastern Australia, from Opuntia inermis (Table 1).

Type: The type strain of Candida mucilagina, UCD (FS\&T) 76-236C, was isolated from rotting tissue of Stenocereus gummosis (agria) near Todos Santos, Baja California Sur, Mexico. It has been deposited in the collection of the Yeast Division of the Centraalbureau voor Schimmelcultures in Delft, The Netherlands as CBS 7071 and in the American Type Culture Collection, Rockville, Md., as ATCC 42174.

Etymology: mucilagina L.L. adj. mucilaginus mucilaginous; referring to the organism's slimy appearance on solid media.

\section{DISCUSSION}

Candida mucilagina is a yeast characteristically associated with cactus rots. It is nonfermentative and produces slimy, almost watery colonies on solid media (Fig. 2). Its principal habitat in the North American Sonoran Desert appears to be rotted tissue of $S$. gummosis (agria), and in Australia, that of $O$. inermis. It is the only species that forms exceptionally slimy colonies that we have isolated from necrotic cactus tissue. It is usually present as a minority organism in cactus-specific yeast communities.

Attempts to induce ascosporulation by cultivating representative strains on a variety of sporulation media were unsuccessful. Similarly, systematic mixing of strains on several media to reveal heterothallism produced neither zygotes nor ascospores.

Superficially, C. mucilagina resembles species of the genus Lipomyces, whose members have their habitat in soil. Similarities include the very slimy appearance of colonies, lack of fermentation, assimilation of a relatively large assortment of carbon compounds, and the production of starchlike compounds on acidic media (e.g., YNB-glucose) that give a blue or blue-green color with Lugol solution. The nuclear DNA base composition of the new species (Table 2) is close to that of several species of Lipomyces (Holzschu, Tredick, and Phaff, unpublished data). In addition, the composition of the capsular slime bears some similarity to the composition of the capsular slime of Lipomyces. The capsular material of $C$. mucilagina consists primarily of two glycoproteins: (i) a mannan-type glycoprotein, containing $90 \%$ D-manniose and precipitable with both concanavalin A and with Fehling solution, and (ii) a glycoprotein containing D-glucose and D-mannose in approximately equimolar proportions and precipitable by concanavalin A but not by Fehling solution. Both glycoproteins contain ca. 5\% uronic acids (Villa and Phaff, unpublished data).

Although C. mucilagina forms no pseudomycelium and could therefore be considered a new

TABLE 2. Nuclear DNA base compositions of representative strains of C. mucilagina

\begin{tabular}{|c|c|c|c|c|}
\hline $\begin{array}{l}\text { Strain } \\
\text { no. }\end{array}$ & Locality $^{a}$ & Substrate $^{a}$ & $\begin{array}{c}\text { Distinctive } \\
\text { physiological } \\
\text { criteria, } \\
\text { assimilation of: }\end{array}$ & $\begin{array}{c}\text { Mol\% G+C } \\
\text { of nuclear } \\
\text { DNA } \pm \mathrm{SD}^{b}\end{array}$ \\
\hline 3 & Todos Santos, Mexico & Stenocereus gummosis & $\begin{array}{l}\text { Maltose-, Sucrose-- } \\
\text { Melezitose- }\end{array}$ & $43.5 \pm 0.1$ \\
\hline $4^{c}$ & Todos Santos, Mexico & Stenocereus gummosis & $\begin{array}{l}\text { Maltose+, Sucrose+, } \\
\text { Melezitose+ }\end{array}$ & $43.2 \pm 0.3$ \\
\hline 8 & $\begin{array}{l}12 \mathrm{~km} \text { South of Mulegé, } \\
\text { Mexico }\end{array}$ & Stenocereus gummosis & $\begin{array}{l}\text { Maltose+, Sucrose+, } \\
\text { Melezitose- }\end{array}$ & $44.0 \pm 0.3$ \\
\hline 11 & $\begin{array}{l}\text { Bahia San Nicholás, } \\
\text { Mexico }\end{array}$ & Stenocereus gummosis & $\begin{array}{l}\text { Maltose-, Sucrose-, } \\
\text { Melezitose- }\end{array}$ & $43.3 \pm 0.01$ \\
\hline 12 & Yarrawonga, Australia & Opuntia inermis & $\begin{array}{l}\text { Maltose }+, \text { Sucrose+, } \\
\text { Melezitose }+\end{array}$ & $43.5 \pm 0.3$ \\
\hline
\end{tabular}

\footnotetext{
${ }^{a}$ See Table 1.

${ }^{b} \mathrm{SD}$, Standard deviation; $\mathrm{G}+\mathrm{C}$, guanine plus cytosine.

c Type strain.
} 
species of the genus Torulopsis Berlese, we are following the proposal by Yarrow and Meyer (9) to include Torulopsis species in their amended genus Candida Berkhout.

\section{ACKNOWLEDGMENTS}

We thank Joanne Tredick for the determination of the DNA base compositions and Yuzo Yamada for determining the coenzyme $Q$ system. We greatly appreciate the assistance of Alexander Russell, Jr., Jean S. Russell, and William R. Johnson with the field collections in Baja California, and of $J$. S. F. Barker, Greg Toll, and Peter East with those in Australia. This research was supported by Public Health Service grant GM-16307-09 from the National Institute of General Medical Sciences to H.J.P., by a grant from the National Science Foundation to W. B. Heed and H. W. Kircher (DEB 74-19148 AO3), and by a grant from the Australian Research Grants Committee (D175/15866) to J. S. F. Barker.

\section{REPRINT REQUESTS}

Address reprint requests to: $H$. J. Phaff, Department of Food Science and Technology, University of California, Davis, CA 95616 .

\section{LITERATURE CITED}

1. Bernardi, G., M. Foures, G. Piperno, and P. P. Slonimski. 1970. Mitochondrial DNAs from respiratory-suf- ficient and cytoplasmic respiratory-deficient mutants of yeast. J. Mol. Biol. 48:23-42.

2. Marmur, J. 1961. A procedure for the isolation of DNA from microorganisms. J. Mol. Biol. 3:208-218.

3. Price, C. W., G. B. Fuson, and H. J. Phaff. 1978. Genome comparison in yeast systematics: delimitation of species within the genera Schwanniomyces, Saccharomyces, Debaryomyces and Pichia. Microbiol. Rev. 42:161-193.

4. Schildkraut, C. L., J. Marmur, and P. Doty. 1962. Determination of the base composition of deoxyribonucleic acid from its buoyant density in $\mathrm{CsCl}$. J. Mol. Biol. 4:430-433.

5. Skerman, V. B. D., V. McGowan, and P. H. A. Sneath (ed.). 1980. Approved lists of bacterial names. Int. J. Syst. Bacteriol. 30:225-420.

6. Starmer, W. T., W. B. Heed, M. Miranda, M. W. Miller, and H. J. Phaff. 1976. The ecology of yeast flora associated with cactiphilic Drosophila and their host plants in the Sonoran desert. Microb. Ecol. 3:1130.

7. Szybalski, W. 1969. Use of cesium sulfate for equilibrium density gradient centrifugation. Methods Enzymol. 12: 330-360.

8. van der Walt, J. P. 1970. Criteria and methods used in classification, p. 34-113. In J. Lodder (ed.), The yeastsa taxonomic study. North-Holland Publishing Co., Amsterdam.

9. Yarrow, D., and S. A. Meyer. 1978. Proposal for amendment of the diagnosis of the genus Candida Berkhout nom. cons. Int. J. Syst. Bacteriol. 28:611-615. 